\title{
Soil Test - Crop Response Correlation with Maize under IPNS System in Inceptisols of Surguja Hills Zone of Chhattisgarh, India
}

\author{
Anupama Xalxo ${ }^{1 *}$, L.K. Shrivastava ${ }^{1}$, Madhulika Singh ${ }^{2}$, \\ Mithun Mishra ${ }^{1}$ and Pushpendra Patel ${ }^{1}$ \\ ${ }^{1}$ Department of Soil Science and Agricultural Chemistry, Indira Gandhi Krishi \\ Vishwavidyalaya, Raipur 492012, Chhattisgarh, India \\ ${ }^{2}$ Department of Agronomy, Indira Gandhi Krishi Vishwavidyalaya, Raipur 492012, \\ Chhattisgarh, India \\ *Corresponding author
}

\section{A B S T R A C T}

\section{Keywords}

Soil test, Inceptisols,

Maize, Nutritional

requirement, INM

approach

Article Info

Accepted:

04 December 2017

Available Online:

10 January 2018
A field experiment was conducted during kharif 2012 in Inceptisols of Northern hills zone of Chhattisgarh to estimate the nutritional requirement, efficiencies of fertilizer, soil test and organic source (FYM) to estimate the fertilizer requirement for varying yield goals of maize crop based on soil test levels using INM approach. Maize crop required $1.59 \mathrm{~kg} \mathrm{~N}$, $0.32 \mathrm{~kg} \mathrm{P}$ and $1.84 \mathrm{~kg} \mathrm{~K}$ for one quintal grain production. Fertilizer and soil test efficiencies estimated were 41.84 and 22.53 percent, respectively for N, 28.28 and 52.67 percent, respectively for $\mathrm{P}$ and 140.33 and 26.40 percent, respectively for $\mathrm{K}$. The FYM contribution in terms of $\mathrm{N}, \mathrm{P}$ and $\mathrm{K}$ were estimated $21.76,4.70$ and 12.81 per cent, respectively. Based on these basic parameters, fertilizer adjustment equation for $\mathrm{N}, \mathrm{P}$ and $\mathrm{K}$ were evolved for different yield targets of maize based on soil nutrients level using FYM as organic component in INM.

\section{Introduction}

Maize (Zea mays L.) is one of the important crop among cereals and it occupies third position in production next to rice and wheat in the world.

In Northern region, maize is gaining popularly and improving climate the livelihood due to favourable climate with limited irrigation facility. The effective fertilizer recommendation should consider crop needs and nutrient already available in the soil.
Continuous use of inorganic nutrients may adversely affect the physico - chemical properties of soil and thereby affect the crop yields. In order to sustain the yield and reduce the dependency on inorganic fertilizer use, conjunctive use of organic manures and fertilizers is very much essential. Targeted yield concept strikes a balance between fertilizing the crop and fertilizing the soil. In the view of above facts, a study on refining the integrated plant nutrient supply on STCR basis was conducted as advocated by Ramamoorthy et al., (1967). 


\section{Materials and Methods}

A field experiment on soil test crop response correlation study was conducted with maize (var. Hisheal) during kharif season 2012 in Inceptisols at Rajmohini Devi College of Agriculture and Research Station, Ajirma, Ambikapur (Chhattisgarh). A special field technique developed by Ramamoorthy et al., (1967) was used for this study. The field was divided in to three long strips and was denoted as $\mathrm{L}_{0}, \mathrm{~L}_{1}$ and $\mathrm{L}_{2}$. These fertility strips had fertility gradient with respect to available $\mathrm{P}$ which was created during previous crop season. Each strip (treated as block) was divided in to 24 equal size plot. The fertilizer treatments constituted of different combinations of various levels of $\mathrm{N}(0,60$, 120 and $\left.180 \mathrm{~kg} \mathrm{ha}^{-1}\right), \mathrm{P}_{2} \mathrm{O}_{5}(0,30,60$ and 90 $\left.\mathrm{kg} \mathrm{ha}^{-1}\right)$ and $\mathrm{K}_{2} \mathrm{O}\left(0,30,60\right.$ and $\left.90 \mathrm{~kg} \mathrm{ha}^{-1}\right)$ and FYM $\left(0,5\right.$ and $\left.10 \mathrm{tha}^{-1}\right)$ were randomly distributed in each strip. The fertilizer materials used were urea, single super phosphate and muraite of potash. Full dose of $\mathrm{P}_{2} \mathrm{O}_{5}$ and $\mathrm{K}_{2} \mathrm{O}$ were applied as basal. The $\mathrm{N}$ was applied in three equal splits applied at basal, full length and tasseling stages. Before application of fertilizer, FYM @ 0,5 and $10 \mathrm{t}$ $\mathrm{ha}^{-1}$ as per treatments structure was applied and thoroughly mixed in soil. Plot-wise soil samples were collected before application of fertilizer and FYM treatments. Soil samples were analyzed for available $\mathrm{N}$ (Subhiah and Asija, 1956), P (Bray, 1948) and K (Hanway and Heidal, 1952). The Hisheal variety of maize crop was sown during the third week of July, 2012 and harvested in fourth week of October, 2012. The yield data for grain and straw for all the plots were recorded at the end of the experiment. Grain and straw samples were analyzed for $\mathrm{N}, \mathrm{P}$ and $\mathrm{K}$ content (Piper, 1966) and total nutrient uptake was computed using grain and straw yield data.

The basic parameter, viz. nutrient requirement $\left(\mathrm{kg} \mathrm{q}^{-1}\right)$, contribution of nutrients from soil, fertilizer and organic sources were calculated as described by Ramamoorthy et al., (1967). These parameters were used for the formulation of fertilizer adjustment equations for deriving fertilizer doses and the soil test based fertilizer recommendations with organic source were prescribed in the form of ready reckoner for desired yield goal of maize.

\section{Results and Discussion}

\section{Soil available nutrients}

The range and mean values of available nutrients $(\mathrm{N}, \mathrm{P} \& \mathrm{~K})$ (Table 1) indicate that soil test $\mathrm{N}, \mathrm{P}$ and $\mathrm{K}$ varied with different fertility strips although soil test $\mathrm{N}$ and $\mathrm{K}$ variations with respect to fertility strip were marginal however, soil $\mathrm{P}$ variation in different strips were quite marked and it increased across the fertility strips.

\section{Crop yield}

Table 2 gives the range and averages of maize yield in relation to different fertility strips. It was observed from the results that there was increasing trends in maize yields from $\mathrm{L}_{0}$ to $\mathrm{L}_{2}$ fertility strip due to increasing P level.

Highest yield of $84.14 \mathrm{q} / \mathrm{ha}$ was observed in $\mathrm{L}_{2}$ strip with a good response to the application of highest dose of fertilizer and $20.86 \mathrm{~g} / \mathrm{ha}$ was observed in the $\mathrm{L}_{0}$ strip without fertilizer (Control).

\section{Estimation of basic parameters}

Results presented in Table 3 show the nutrient requirement (NR) for $\mathrm{N}, \mathrm{P}$ and $\mathrm{K}\left(\mathrm{kg} \mathrm{q}^{-1}\right)$, efficiencies of fertilizer (Ef), soil test (Es) and FYM estimated based on the basic formula. The maize required about $1.59 \mathrm{~kg} \mathrm{~N}, 0.32 \mathrm{~kg} \mathrm{P}$ and $1.84 \mathrm{~kg} \mathrm{~K}$ to produce one quintal of grain. Fertilizer efficiencies for $\mathrm{P}$ were less than soil test efficiencies. 
Table.1 Range and mean value of available N, P and K (kg/ha)

\begin{tabular}{|c|c|c|c|c|c|}
\hline Soil Nutrients & $\mathrm{L}_{0}$ & $\mathrm{~L}_{1}$ & $\mathrm{~L}_{2}$ & SD & CV \% \\
\hline $\begin{array}{l}\text { Alkaline } \\
\mathrm{KMnO}_{4}-\mathrm{N}\end{array}$ & $\begin{array}{l}197-229 \\
(209)\end{array}$ & $\begin{array}{l}192-217 \\
(206)\end{array}$ & $\begin{array}{l}197-229 \\
(211)\end{array}$ & 9.12 & 4.37 \\
\hline Bray's & $\begin{array}{c}10.37-20.52 \\
(14.15)\end{array}$ & $\begin{array}{c}19.22-38.70 \\
(29.98)\end{array}$ & $\begin{array}{c}30.05-44.21 \\
(37.56)\end{array}$ & 10.70 & 39.92 \\
\hline $\begin{array}{l}\text { Amm. acetate } \\
\text { extractable } K\end{array}$ & $\begin{array}{c}183-289 \\
(219)\end{array}$ & $\begin{array}{c}172-324 \\
(233)\end{array}$ & $\begin{array}{c}181-349 \\
(244)\end{array}$ & 42.31 & 18.24 \\
\hline
\end{tabular}

Values in parenthesis are average data

Table.2 Range and mean values of maize (Var. Hisheal) yield (q/ha)
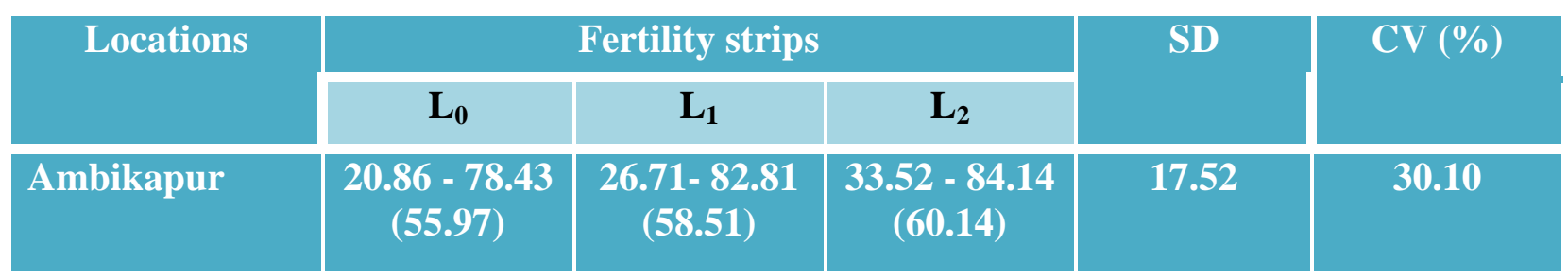

Table.3 Nutrient requirement, fertilizer, soil and FYM efficiencies

\begin{tabular}{|l|l|l|l|l|}
\hline Nutrient & $\begin{array}{l}\text { NR } \\
\left(\mathrm{kg} \mathrm{q}^{-1}\right)\end{array}$ & $\begin{array}{l}\text { Fertilizer } \\
\text { efficiency } \\
(\%)\end{array}$ & $\begin{array}{l}\text { Soil } \\
\text { efficiency } \\
(\%)\end{array}$ & $\begin{array}{l}\text { FYM efficiency } \\
(\%)\end{array}$ \\
\hline $\mathbf{N}$ & 1.59 & 41.84 & 22.53 & 21.76 \\
\hline $\mathrm{P}$ & 0.32 & 28.28 & 52.67 & 4.70 \\
\hline $\mathrm{K}$ & 1.84 & 140.33 & 26.40 & 12.81 \\
\hline
\end{tabular}

Table.4 Fertilizer adjustment equation estimated based on response data (Ambikapur)

\begin{tabular}{|l|}
\hline Fertilizer adjustment equations \\
\hline FN $=3.81$ Y $-0.54 \mathrm{SN}-0.52$ FYM \\
\hline FP $=1.13$ Y $-1.86 \mathrm{SP}-0.17 \mathrm{FYM}$ \\
\hline FK $=1.31$ Y $-0.19 \mathrm{SK}-0.09 \mathrm{FYM}$ \\
\hline
\end{tabular}

Where, FN, FP and FK are fertilizer $\mathrm{N}_{1} \mathrm{P}_{2} \mathrm{O}_{5}$ and $\mathrm{K}_{2} \mathrm{O}\left(\mathrm{Kg} \mathrm{ha}^{-1}\right)$ respectively. FYM is Farm Yard Manure $\left(\mathrm{t} \mathrm{ha}^{-1}\right)$. SN, SP and SK are soil test values $\left(\mathrm{kg} \mathrm{ha}^{-1}\right)$ for $\mathrm{KMnO}_{4} \mathrm{~N}$, Bray 's P and ammonium acetate extractable $\mathrm{K}$ and $\mathrm{Y}$ is targeted yield in $\mathrm{q} \mathrm{ha}^{-1}$. 
Table.5 Ready Reckoners for soil test based fertilizer $\mathrm{N}_{2} \mathrm{O}_{5}$ and $\mathrm{K}_{2} \mathrm{O}$ recommendation of hybrid maize (Hisheal) in Inceptisols with 5 tonnes of FYM

\begin{tabular}{|c|c|c|c|c|c|c|c|c|c|c|c|}
\hline \multirow{2}{*}{\multicolumn{3}{|c|}{$\begin{array}{c}\text { Soil Test values } \\
\text { (kg/ha) }\end{array}$}} & \multicolumn{9}{|c|}{ Yield Target of maize (q/ha) } \\
\hline & & & \multicolumn{3}{|c|}{60} & \multicolumn{3}{|c|}{70} & \multicolumn{3}{|c|}{80} \\
\hline $\mathbf{N}$ & $\mathbf{P}$ & $\mathbf{K}$ & FN & FP & FK & FN & FP & FK & FN & FP & FK \\
\hline 150 & 4 & 200 & 145 & 60 & 50 & 183 & 71 & 63 & 221 & 82 & 76 \\
\hline 175 & 6 & 225 & 132 & 56 & 45 & 170 & 67 & 58 & 208 & 78 & 71 \\
\hline 200 & 8 & 250 & 118 & 52 & 40 & 156 & 63 & 53 & 194 & 75 & 66 \\
\hline 225 & 10 & 275 & 105 & 48 & 35 & 143 & 60 & 49 & 181 & 71 & 62 \\
\hline 250 & 12 & 300 & 91 & 45 & 31 & 129 & 56 & 44 & 167 & 67 & 57 \\
\hline 275 & 14 & 325 & 78 & 41 & 26 & 116 & 52 & 39 & 154 & 64 & 52 \\
\hline 300 & 16 & 350 & 64 & 37 & 21 & 102 & 48 & 34 & 140 & 60 & 47 \\
\hline 325 & 18 & 375 & 51 & 33 & 16 & 89 & 45 & 30 & 127 & 56 & 43 \\
\hline 350 & 20 & 400 & 37 & 30 & 12 & 75 & 41 & 25 & 113 & 52 & 38 \\
\hline 375 & 22 & 450 & 24 & 26 & 7 & 62 & 37 & 20 & 100 & 49 & 33 \\
\hline 400 & 24 & 500 & 10 & 22 & 2 & 48 & 34 & 15 & 86 & 45 & 28 \\
\hline
\end{tabular}

Contrary to this, fertilizer efficiencies for nitrogen and potash were observed higher than soil test efficiencies. The efficiency of FYM for $\mathrm{N}$ was found to be higher and minimum value was observed with phosphorous.

The fertilizer adjustment equations for N, P and $\mathrm{K}$ with FYM have been presented in Table 4. The ready reckoners for fertilizer $\mathrm{N}, \mathrm{P}_{2} \mathrm{O}_{5}$ and $\mathrm{K}_{2} \mathrm{O}$ along with 5 tonnes of FYM for specific yield targets of maize (var. Hisheal) is presented in Table 5. The ready reckoners show that the fertilizer requirements decrease with increase in soil test values. Therefore a slightly lower yield target may be considered for poor farmers.

\section{References}

Bray, H.R. and Kurtz, L.T.1945. Determination of organic and available forms of phosphorus in soils. Soil Sci., 9:39-46.

Bray, R.H. 1948. Requirements for successful soil test. Soil Science, 66:83-89.

Hanway, J.J., and Heidal, H. 1952. Soil analysis methods used in Iowa state soil testing labn. Agronomy, 57:1-37.

Muhr, G.R., Datta, N.P., Subramoney, H., Leley, V.K. and Donahue, R.L. 1965. Soil testing in India. United States Agronomy for International development mission on India, New Delhi.

Piper, C.S. 1966. Soil and Plant Analysis. Acaddemic Press, New Delhi, Pp. 368.

Ramamoorthy, B., Narasimhan, R.L. and Dinesh, R.S. 1967. Fertilizer application for specific yield targets of Sonara-64. Indian Farming, 17(5): 43-45.

Subbiah, B.V. and Asija, G.L. 1956. A rapid procedure the estimation of available nitrogen in soils. Curr. Sci., 25:259-260.

\section{How to cite this article:}

Anupama Xalxo, L. K. Shrivastava, Madhulika Singh, Mithun Mishra and Pushpendra Patel. 2018. Soil Test - Crop Response Correlation with Maize under IPNS System in Inceptisols of Surguja Hills Zone of Chhattisgarh, India. Int.J.Curr.Microbiol.App.Sci. 7(01): 408-411.

doi: https://doi.org/10.20546/ijcmas.2018.701.046 